\title{
Surface Magnetic Properties and Magnetization Dynamics of Magnetite Nanoparticles Doped with Platinum Ions
}

\author{
M. M. Bataiev, Yu. M. Bataiev, O. M. Lavrynenko, and O. A. Kornienko \\ I. M. Frantsevych Institute for Problems of Materials Science, N.A.S. of Ukraine, \\ 3, Krzhyzhanovs'kyy Str., \\ UA-03142 Kyiv, Ukraine
}

Magnetization dynamics and surface magnetic properties of the magnetite nanoparticles doped with platinum cations are studied on the microscopic level using EPR spectroscopy. The composite samples are formed on the steel surface contacted with Pt-containing water solutions under the rotation-corrosion dispergation conditions. Increase in $\mathrm{Pt}$ part in the structure of nanocomposites is accompanied by the corresponding shift of the EPR lines towards higher energies. Absorption EPR spectroscopy demonstrates specific spectroscopic characteristics for Pt-containing samples under controlled conditions. Spectroscopic parameters for the Pt samples obtained by high-quality processing and analysis provide appropriate mathematical model for the EPR spectroscopy results. Procedure of interpolation and fit for the EPR experimental data gives opportunity to develop a theoretical model for a set of samples. From EPR absorption spectra analysis for Pt-bearing samples, it is concluded that the Lorentz theoretical model is the most applicable for $\mathrm{Pt}$ data. The correlation between the concentration of $\mathrm{Pt}$ ions and the location of the corresponding EPR line in the spectrum is observed. An increase in Pt concentration in the particle structure leads to a corresponding shift of the EPR line towards higher energies. The change in magnitude intensity of the obtained spectra is described within the scope of the theory of Knight shift in ferromagnetics.

Динаміку магнетування та поверхневі магнетні властивості наночастинок магнетиту, леґованих катіонами Платини, вивчали на мікроскопічному рівні за допомогою ЕПР-спектроскопії. Композитні зразки формувалися на сталевій поверхні, що контактувала з водними розчинами, які містять $\mathrm{Pt}$, в умовах обертально-корозійного диспергування. Збільшення Pt y структурі нанокомпозитів супроводжується відповідним зсувом ліній ЕПР у бік вищих енергій. Абсорбційна ЕПР-спектроскопія демонструє специфічні спектроскопічні характеристики для Pt-вмісних зразків у контрольованих умовах. Спектроскопічні параметри для зразків Pt, одержані високоякісним обробленням та аналізою, дають від- 
повідний математичний модель для результатів спектроскопії ЕПР. Процедура інтерполяції та придатність для експериментальних даних ЕПР дає можливість скласти теоретичний модель для набору зразків. 3 аналізи спектрів поглинання ЕПР для зразків, що містять $\mathrm{Pt}$, зроблено висновок, що теоретичний Лорентців модель є найзастосовнішим для даних Pt. Спостерігалася кореляція між концентрацією йонів Pt та розташуванням відповідної лінії ЕПР у спектрі. Збільшення концентрації Pt у структурі частинок приводить до відповідного зсуву лінії ЕПР у бік вищих енергій. Зміну інтенсивности величини одержаних спектрів було описано в рамках теорії Найтового зсуву в феромагнетиках.

Динамика намагниченности и поверхностные магнитные свойства наночастиц магнетита, легированных катионами платины, изучены на микроскопическом уровне с помощью ЭПР-спектроскопии. Образцы композита формировались на поверхности стали, контактирующей $\mathrm{c}$ Ptсодержащими водными растворами в условиях вращательнокоррозионного диспергирования. Увеличение доли $\mathrm{Pt}$ в структуре нанокомпозитов сопровождается соответствующим сдвигом линий ЭПР в сторону более высоких энергий. Абсорбционная ЭПР-спектроскопия демонстрирует специфические спектроскопические характеристики для Ptсодержащих образцов в контролируемых условиях. Спектроскопические параметры для образцов Pt, полученных высококачественной обработкой и анализом, обеспечивают соответствующую математическую модель для результатов спектроскопии ЭПР. Процедура интерполяции и подгонки к экспериментальным данным ЭПР даёт возможность составить теоретическую модель для набора образцов. Из анализа спектров поглощения ЭПР для образцов, содержащих Рt, сделан вывод, что теоретическая модель Лоренца является наиболее применимой для данных Pt. Обнаружена корреляция между концентрацией ионов $\mathrm{Pt}$ и расположением соответствующей линии ЭПР в спектре. Увеличение концентрации Pt в структуре частиц приводит к соответствующему сдвигу линии ЭПР в сторону более высоких энергий. Изменение величины интенсивности полученных спектров описано в рамках теории смещения Найта в ферромагнетиках.

Key words: magnetite nanoparticles doped with Pt, EPR spectroscopy, magnetization dynamics, surface magnetic properties.

Ключові слова: наночастинки магнетиту, леґовані Pt, спектроскопія ЕПР, динаміка намагнетованости, поверхневі магнетні властивості.

Ключевые слова: наночастицы магнетита, легированные $\mathrm{Pt}$, ЭПРспектроскопия, динамика намагниченности, поверхностные магнитные свойства.

(Received 4 December, 2019; in final version, 12 December, 2019)

\section{INTRODUCTION}

Nowadays, the interest in the creation of new kind of composite na- 
nomaterials is closely connected with their practical application for technical and biological aims. So, the superparamagnetic magnetite particles doped with precious metals, including platinum, may be used as an effective agent for diagnostic and anticancer therapy [1]. The formation of magnetite particles in the presence of noble metal cations results in the changes of magnetic characteristics of the samples, their morphology, physical and chemical properties as well [2].

Hence, complex of unique chemical and magnetic characteristics of nanomagnetite when precious metal cations are present in their crystal structure or on the particle surface gives the possibility to obtain new preparative line for biomedicine. One of the powerful methods for the investigation of the surface magnetic properties is EPR spectroscopy.

For example, EPR measurements of the nanocrystalline magnetite particles (the lattice parameter $a=0.8409 \mathrm{~nm}$ ) synthesized by a chemical co-precipitation method, confirmed the superparamagnetic nature of the samples. Their saturation magnetization was $42 \mathrm{emu} / \mathrm{g}$ [3]. According to Ref. [4], it is possible to maximize catalytic activity of the Pt-bearing catalyst through the control not only of $\mathrm{Pt}$ size and shape but also of its interaction with magnetite nanoparticles [5]. Generally, the magnetic properties of particles are determined by many factors including: (1) the chemical composition of the samples; (2) type of their crystal lattice and the presence or absence of structural defects; (3) particle size, their homogeneity, shape and morphology; (4) the possible interaction of particles with their surrounding matrix and neighbouring particles. Hence, the control of several parameters such as size, shape, composition and structure of nanoparticles, strongly effects on the magnetic characteristics of disperse materials based on them [6].

The aim of the present work was to study magnetization dynamics and surface magnetic properties of the magnetite nanoparticles doped with platinum on the microscopic level with high resolution and sensitivity of EPR spectroscopy [7]. The emphasis was made on the $\mathrm{Pt}^{0}$-domain structures included into substrate $\mathrm{Fe}_{3} \mathrm{O}_{4}$ using the EPR spectroscopy study. The magnetic properties of $\mathrm{Pt}^{0}$ domains under various conditions were detected by spectroscopy at room temperature. A number of mathematical models are used to prove the equations for magnetic characteristics and properties of the domain structures. Size, shape, the surrounding of domains as well as temperature may influence magnetic properties of the particles. The EPR spectroscopy study allows obtaining detailed information for changes in magnetic parameters of a certain domain or structure under controlled physical or chemical conditions during the experimental study.

The physical magnetic properties of the particles were determined 
by a spectral line. The characteristics of the line that included intensity $\left(I_{\max }\right)$, position $\left(H_{c}\right)$, broadening (FWHM), area under the curve $(A)$ and shape of the line allow making the conclusion about mathematical description for properties of the particular particle. Magnetic parameters of spectral line in the spectrum give the possibility to determine and identify certain particle or an object by EPR spectroscopy.

The controlled changes in parameters of the spectral lines provide additional information about characteristics of a certain atom, particle or domain. An additional information included concentration of atoms, number of spins, type of spins, existence and presence of ferromagnetic and paramagnetic properties, atomic number, atomic mass, and type of the ions, the presence of isotopes, existence of additional atoms or chemical complexes.

Controlled changes in the spectral parameters give the reason to make conclusion about composition and characteristics of material, number of lattice parameters, size of the particles, and dimensionality of the objects, magnetic properties of particles as well as matrix they included in. It implies complex procedure of EPR spectroscopy data processing due to complex mathematical model consideration that included differential equation description. It also included nonlinear mathematical procedures of description for complex spectra and EPR spectroscopy for hyperfine structures that imply additional terms in the mathematical description. The physical consideration terms requires additional tables to properly study and interpret obtained results.

\section{EXPERIMENTAL/THEORETICAL DETAILS}

\subsection{Synthesis of Nanoparticles}

Magnetite nanoparticles doped with platinum cations were formed on the iron-carbon alloy (Steel 3-St3) via the rotation-corrosion dispergation (RCD) route [8]. The phase formation process was performed under free entrance of air oxygen and carbon dioxide onto the electrode surface. Before every experiment, the surface of St3 was exposed to mechanical treatment and chemical activation procedure. The initial concentration of $\mathrm{Pt}^{4+}$ in the solution was chosen in the range from 0.5 to $5 \mathrm{mg} \cdot \mathrm{dm}^{-3}$. The phase formation process was carried out up to $72 \mathrm{~h}$ until the system reached the stationary state. As-prepared magnetite powders doped with Pt were detected using: (1) x-ray diffraction method (XRD) to determine the phase composition and the primary particle size; (2) x-ray fluorescence spectroscopy (XRFS) to find corresponding metal ratios; (3) magne- 
tometry to measure the magnetic properties of the samples such as saturation magnetization, remained magnetization, and coercitivity.

\subsection{Methodology of the EPR Study}

Received samples were measured by methodology of electron paramagnetic resonance (EPR). The study of magnetic dynamics and surface properties of the ferromagnetic Pt-bearing magnetite samples had been performed. Magnetic characteristics and magnetic structure were measured at the microscopic level under EPR conditions with high corpulence and high resolution. Magnetic structure of ferromagnetic was obtained by experimental EPR measurements of the Pt-bearing magnetite samples. The magnetic characteristics of $d-{ }^{78} \mathrm{Pt}$ metal were studied at temperature $300 \mathrm{~K}$.

\subsection{EPR Equipment}

The EPR experimental measurements were made using commercial Radiopan $2547 \mathrm{SE} / \mathrm{X}$ spectrometer equipped by TE resonant cavity. Liquid nitrogen cryostat unit for temperature dependence measurements and investigation in the range of $77-300 \mathrm{~K}$ is also imbedded into experimental EPR spectroscopy [9] apparatus. For EPR spectroscopic measurements, sealed glass tubes S16 were employed.

The results of the measurements demonstrate compliance with the theoretical model for the EPR spectra of nanomagnetite doped with $\mathrm{Pt}$ performed by the application of the radiospectrometer $\mathrm{Ra}$ diopan $2547 \mathrm{SE} / \mathrm{X}$, equipped with TE resonator RCX $660 \mathrm{~A}$, electromagnet ER 2505 and the high frequency unit MS 212 with a frequency of $9.3 \mathrm{GHz}$. The module with a rare-nitrogen and a residual unit RPG 221 for measurements in the range from $77 \mathrm{~K}$ to $273 \mathrm{~K}$ complement the installation of EPR spectroscopy setup.

The EPR spectroscopy meter type ZS 202 equipped with magnetometer type JTM 247 and digital system scan CUP 203, the operating switch PF 204 and high frequencies block MS 212, and unit of modulation type MW 203 and microwave frequency unit type BM 212 are used in the experiment.

The electromagnet ER 2505 with the PZP 80 power supply unit and an HSP 203 field stabilizer were used in the studies along with the AM 247 magnetometer measuring head and the probe with the SH 203 Hall sensor and the SR 211 control unit.

\subsection{Theoretical Models to Describe EPR Data}

Generally, the obtained results showed good agreement with the 
theoretical model. When the spectra were processing, the Origin and MatLab packages were used to carry out the procedure of integration, interpolation, and fitting of the obtained spectra. To improve the result, the spectrum was recorded at various values (1525 ref. units) of the radiation power (Receiver Gain). All curves obtained experimentally were processed using one formula. A distribution formula was chosen depending on the result of processing the curves. We considered the Lorentz distribution formula and the Gaussian distribution formula for fitting the obtained spectra. To obtain the best result with $R$-square coefficient value (Adjacent $R$ Squared) at value of 0.99 , the final versions were drawn by application of a suitable theoretical model for this ferromagnetics.

The shape of the spectrum was determined by solving the mathematical problem of a differential equation of the first order for the Lorentz curve. So, the below-presented formula (1) describes the form of the differential equation for this problem:

$$
m x^{\prime \prime}+q x^{\prime}+p x=e E^{\prime} .
$$

The solution method was derived in the form of the exponential functions. For formula (1), the following equality holds:

$$
E^{\prime}=E_{0} \exp (-i w t)
$$

The following expression can be written for the coordinate:

$$
r=r_{0} \exp (-i w t) .
$$

The functions (2), (3) allow finding the form of the solution for differential equation.

The form of the solution is represented in formula (4) for the $r$ value; for the above-mentioned equations, it is fair to write as follows:

$$
r=\frac{e E}{m\left(w_{0}^{2}-w^{2}\right)} \text {. }
$$

To find the distribution function for the differential equation, it is necessary to multiply the $r$-value by the number of atoms and the charge. Equation (5) represents the distribution function for the differential equation in terms of mass, charge, and a number of particles presented in distribution. From here, we obtain the value of $P$ :

$$
P=N p=N e r=N \frac{e^{2}}{m} \frac{E^{\prime}}{w_{0}^{2}-w^{2}} .
$$

The solution of this equation is the function, 


$$
y=y_{0}+\frac{2 A}{\pi} \frac{w}{4(x-x c)^{2}-w^{2}} .
$$

Additional coefficient value for $y$ is equal to

$$
y_{c}=y_{0}+\frac{2 A}{\pi w} \text {. }
$$

A set of spectroscopic characteristics of nanomagnetite doped with $\mathrm{Pt}$ corresponding high-resolution spectra is processed using the Origin and MatLab software packages and interpreted according to a theoretical model.

\section{RESULTS AND DISCUSSION}

\subsection{Characteristics of the Magnetite Nanoparticles Doped with Platinum Cations}

According to XRD data (Fig. 1), performing the phase formation process under the RCD conditions permits to obtain the homogeneous nanopowder typical for the magnetite structure (JCPDS file No 19-0629). In addition, the small reflexes of $\mathrm{Pt}^{0}$ are clearly seen in the XRD-patterns. Average primary particle size equals $\cong 20 \mathrm{~nm}$. Xray fluorescence spectroscopy confirms the inclusion of two metals in the crystal lattice of the samples, namely, in our case, Fe and Pt. Hence, we may estimate the prepared via RCD route nanopowders as magnetite doped with platinum. The measurement of magnetic

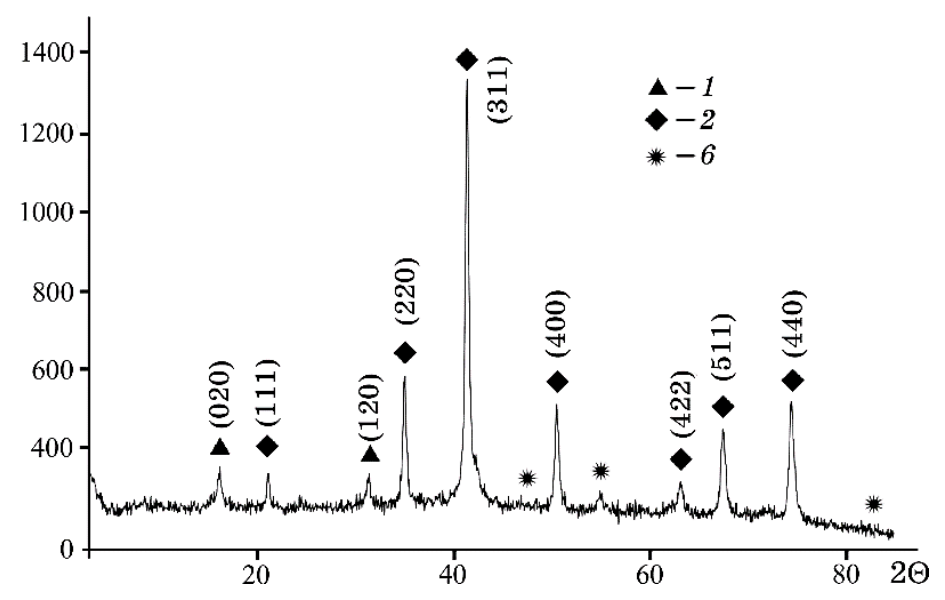

Fig. 1. XRD-pattern of magnetite particles doped with platinum. Numbers correspond to: 1-Lepidocrocite; 2-Magnetite; 6 -Platinum. 
characteristics of the platinum-containing magnetite nanoparticles points to the absence of remained magnetization and coercitivity. Hence, all samples belong to superparamagnetics. As revealed, the saturation magnetization $\left(M_{s}\right)$ of magnetite particles formed in the presence of platinum ions does not depend on the initial $\mathrm{Pt}^{4+}$ concentration in the solutions. Therefore, in all cases, approximation of $M_{s}$ lies within the narrow range $60-62 \mathrm{~A} \cdot \mathrm{m}^{2} \cdot \mathrm{kg}^{-1}$.

\subsection{EPR Spectroscopy}

The EPR line spectral parameters were analysed for each of the spectra for the samples of nanomagnetite doped with Pt. The line shape obtained on the EPR spectrometer was appropriate, and the line width, centre line remained constant for Pt-containing magnetite. The measurement quality of the machining, interpolation, and fitting procedures by the theoretical model is confirmed by the value of Adj. $R$-square (adjusted squared $R$ ) is equal to 0.99 for each of the samples.

The results of the study of Pt-containing magnetite by EPR spectroscopy are shown in Fig. 2. As follows from the results, the introduction of $\mathrm{Pt}$ into the matrix of $\mathrm{Fe}_{3} \mathrm{O}_{4}$ leads to an increase in the spectral line intensity for $\mathrm{Pt}$ at 2000 Gauss. The line intensity at 2000 Gauss in the EPR spectrum corresponds to the presence of

EPR Spectroscopy for Pt 0.5-Pt 5 Samles at $T=300 \mathrm{~K}$

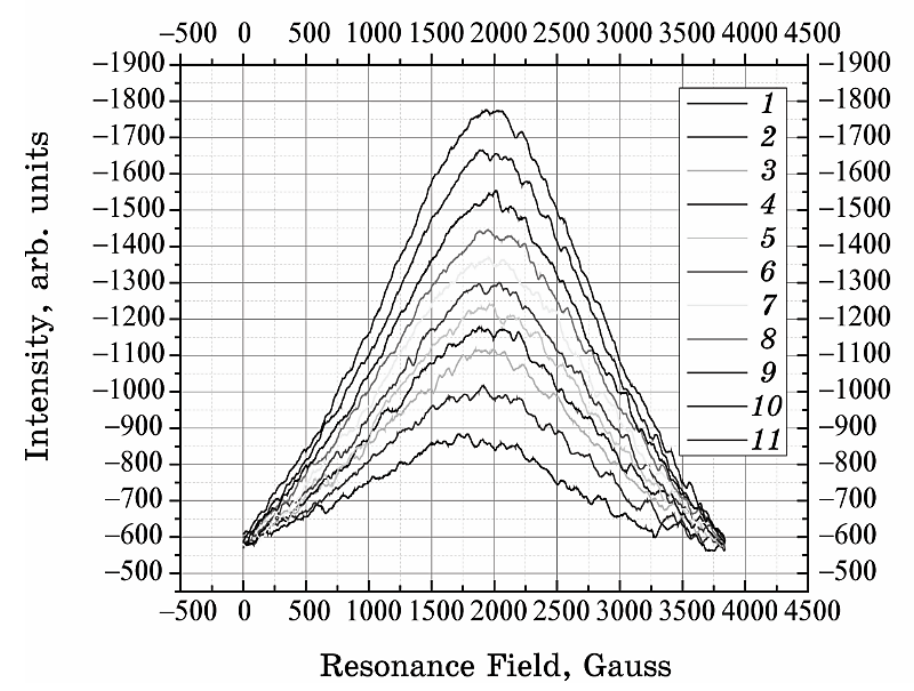

Fig. 2. EPR-intensity dependences of absorption spectra for the $\mathrm{Fe}_{3} \mathrm{O}_{4} \& \mathrm{Pt}$ samples for a set of attenuation amplitudes. 
$\mathrm{Fe}_{3} \mathrm{O}_{4}$ as the main phase.

In this experiment, the EPR lines that belong to the Pt ions into the $\mathrm{Fe}_{3} \mathrm{O}_{4}$ phase can be detected and measured. The intensity of the line characterizes the relative proportion of $\mathrm{Pt}$ ions in the samples. Increasing the mass fraction twice results in a linear increase in the line intensity and area under the EPR spectrum curve.

In these samples, there is also the increase in intensity of the EPR spectral lines of the Pt in the spectral range from 0 to 3500 Gauss. A linear increase of the receiver gain leads to a corresponding increase in the intensity of EPR spectrum. The magnitude of the increase of the spectrum is described within the groundwork for the spectral lines in Pt-containing magnetite.

As follows from Fig. 3, the Pt intensity increases, the line intensity and the area under the curve of the EPR spectrum also increases according to the formation for the EPR spectral lines. The line form of the EPR spectrum remains constant for ions Pt and has the Lorentz line shape and meets theoretical models.

Based on the results of the EPR spectroscopy, the theoretical model of the magnetic characteristics of Pt-containing nanomagnetite has been established in a wide range of experimental conditions. For the experimental data, the dependence of intensity of the EPR lines is in accordance with the theoretical model. The characteristics for the $\mathrm{Pt}$ samples, such as line width, centre of line, and line shape of the EPR, remain constant. The line height and the plane under the curve show

EPR Spectroscopy for Pt 0.5-Pt 5 Samples at $T=300 \mathrm{~K}$

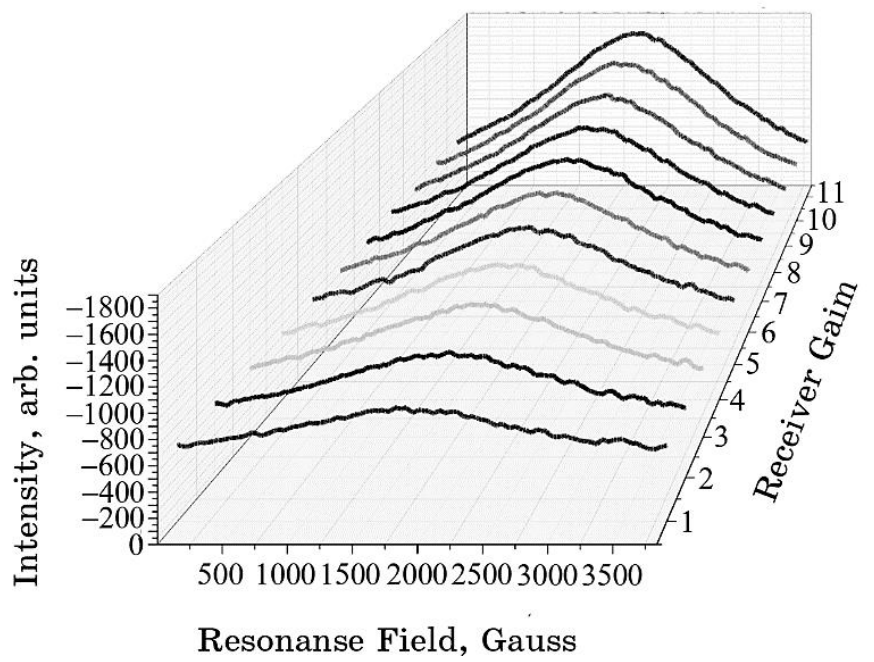

Fig. 3. EPR-intensity dependences of absorption spectra of the $\mathrm{Fe}_{3} \mathrm{O}_{4} \& \mathrm{Pt}$ samples. 
linear growth with the concentration of the ferromagnetic phase.

The relationship between the concentration of $\mathrm{Pt}$ ions and the position of the corresponding EPR line in the spectrum was investigated. An increase in $\mathrm{Pt}$ concentration leads to a corresponding shift of the EPR line towards higher energies. The magnitude of the shift in the spectrum is described in the framework of the theory of Knight shift in ferromagnets.

\section{CONCLUSION}

The intensity dependences of EPR absorption spectra provide specific spectroscopic characteristics for Pt-containing samples under varied conditions. Processed set of spectra was high quality integrated and fit by theoretical model. Corresponding parameters of fit were obtained and analysed for every spectrum for each sample. The shape of the line was relevant and the width and centre of the line remained constant for each set of samples. The intensity and the area under the curve demonstrate linear growth for each $\mathrm{Pt} 0.5-\mathrm{Pt}$ 5 samples. The quality of the measurements, procedures, interpolation and fit by theoretical model are proved by the value of Adj. $R$ square that equals to 0.99 for a set of the samples.

It was shown the consistence of the theoretical model with respect to the magnetite particles doped with $\mathrm{Pt}$, which were formed in the wide range of platinum concentration. The intensity dependence of the EPR experimental data is in the perfect agreement with the theoretical model. Such characteristics for Pt-bearing samples as width, centre and the shape of the EPR lines remained constant. The height of the line and the area under the curve demonstrate linear growth with attenuation amplitude.

\section{REFERENCES}

1. A. Figuerola, A. Fiore, T. Pellegrino, R. Di Corato, A. Falqui, C. Giannini, E. Micotti, A. Lascialfari, M. Corti, R. Cingolani, D. Cozzoli, and L. Manna, The 5th Intern. Congr. of NanoBioCleanTech (2008).

2. E. Bertolucci, Chemical and Magnetic Properties Characterization of Magnetic Nanoparticles, IEEE, 978-1-4799-6144-6 (2015).

3. G. S. Shahane, Magnetohydrodynamics, 49, Nos. 3-4: 317 (2013).

4. C. Wang, Nano Lett., 9, No. 4: 1493-6 (2009).

5. $\quad$ P. J. Alonso, J. Phys. Chem. Solids, 52, No. 8: 975 (1991).

6. S. P. Gubin, Chemistry Success, 74, No. 6: 539 (2005).

7. M. Farle, Rep. Prog. Phys., 61: 755 (1998).

8. O. M. Lavrynenko, O. Yu. Pavlenko, and Yu. S. Shchukin, Nanoscale Research Letters, 11: 67 (2016); https://doi.org/10.1186/s11671-016-1267-2.

9. Spectrometer EPR SE/X 2547. Manual. Radiopan (2016). 